\title{
PERAN PENDIDIK SEBAGAI DESAINER STRATEGI INSTRUKSIONAL DALAM MENINGKATKAN KUALITAS PEMBELAJARAN DI SD
}

\author{
Yohanes Vianey Sayangan \\ Sekolah Tinggi Keguruan dan Ilmu Pendidikan Citra Bakti Ngada, Flores, NTT, Indonesia \\ Korespondensi. E-mail: viany.sygn.wikul@gmail.com
}

\begin{abstract}
Abstrak
Penelitian ini dirancang dengan tujuan untuk menemukan dua masalah besar yaitu persoalan ketiakmampuan para guru untuk menjadi disainer strategi instuksional, dan bagaimana mencari cara untuk meningkatkan kompetensi para guru agar dapat menjadi perancang strategi pembelajaran secara handal sehingga mampu meningkatakan kualitas pembelajaran. Adapun tujuan dari penelitian inia adalah untuk menganalisis persoalan ketiakmampuan para guru untuk menjadi disainer strategi instuksional dan menemukan cara yang tepat untuk meningkatkan kompetensi para guru agar dapat menjadi perancang strategi pembelajaran secara handal sehingga mampu meningkatakan kualitas pembelajaran. Metode penelitian ini menggunakan pendekatan kualitaitaf dengan menggulirkan triangulasi data.Adapun hasil penelitian ini menunjukkan bahwa dampak dari kondisi social dan budaya masyarakat yanag statis terhadap perubahan turut mempengarauhi kinerja guru.Factor motivais yang rendah, dan keterbatasan sumber pengetahuan juga mempengaruhi kemampuan guru untuk menjaadi desainer strategi insntruksional.Akhirnya, dapat disimpulkan bahwa untuk dapat meningkatkan kualifikasi guru berkaitan dengan menjadi seorang desainer strategi instruksional maka yang perlu dilakukan adalah melakukan pendidikan dan pelatihan tentang mendesain strategi instruksional, serta mempraktekan merancang strategi instruksional di sekolah oleh para guru.
\end{abstract}

Kata Kunci: Pendidik, Desaineer, Strategi Instruksional, Kualitas Pembelajaran

\section{THE ROLE OF EDUCATORS AS DESIGNERS OF INSTRUCTIONAL STRATEGIES TO IMPROVE LEARNING QUALITY IN PRIMARY SCHOOLS}

\begin{abstract}
This Research is designed to find two main problems that is disability teachers to be a designer of instructional strategy and how to increase competency of techers in desgning instructional strategy in order to increase instructional quality. The goals of this research are to analysis the factof of disability teachers to be a designer of instructional strategy and to find manner to increase competency of techers in desgning instructional strategy in order to increase instructional quality. Research metohod is qualitative approach. Data was collect with observation and interview by data triangulation. Researche results indicates that social and cultural condition of static society have impact on teacher performance, motivation factor and limitations of science resource also affect maturity stage of teacher ability in designing instructional strategy. Finally, conclusion the result that in order to increase teachers qualification around to be a designer in shape instructional strategy can be done by making education and training activity in realting with design instructional strategy, implementing desaign insstructonal strategy for teachers in schools.
\end{abstract}

Keywords: Educators, Designer, Instructional Strategy, Instructional Quality

Copyright (2018, JRPD, ISSN 2615 - 1723 (Print), ISSN 2615 - 1766 (Online) 


\section{PENDAHULUAN}

Guru yang kreatif, inovatif, penuh semangat, empaati dan luwes berperan sebagai fasilitator merupakan gambaran guru yang ideal. Namun demikian, guru yang ideal tidak mudah ditemukan atau diciptakan. Guru yang idel sangat dibutuhkan untuk memberikan pegangan hidup berupa pengalaman kognitif, afektif dan motorik bagi generasi muda.

Guru yang berkualitas tidak hanya mampu berperan sebagai pengajar yang handal, akan tetapi juga berperan sebagai pendidik yang hebat. Guru perlu memiliki penguasaan yang baik terhadap materi atau substansi keilmuan dan memiliki kemampuan dalam menyampaikan maateri atau substansi pelajaran secara efektif dan efisien serta sekaligus membentuk karakter peserta didik. Peningkatan kualitas guru tidak hanya ditentukan oleh pendidikan dan pelatihan guru semata, tapi juga dengan kebijakan dan aturan yang berlaku tentang tugas, kewenangan dan kinerja guru dalam menjalankan tugas.

Guru harus memiliki kreativitas untuk menciptakan pengalaman belajar yang mendorong siswa menjadi pembelajar sepanjang hayat. Saat ini aturan dan kebijakan tentang tugas dan kinerja guru kerap dimaknai sebagai suatu resep baku yang disediakan oleh pemerintah pusat. Akbiatnya guru hanya berperan sebagai operator yang manjalankan tugasnya secara mekanistis.

Morin (2013:14) mengemukakan bahwa: “... Tugas guru yang paling fudamental pada abad XXI adalah menyiapkan anak agar siap menghadapi realitas kehidupan yang kian kompleks dan serba tidak jelas. Dunia pendidikan saat ini khususnya guru, tidak mengajarkan bagaimana menjadi manusia yang utuh, tidak juga diajarkan untuk memahami hubungan antar individu yang justru penting untuk menekan konflik dan perpecahan yang kian sering terjadi. Materi ajaar yang dipelajari di sekolah seakan terlepas dan tidak sterkait degan kehidupan sehari-hari".

Guru tidak mampu menunjukkan sikap kreatif karena aturan dan kebijakan tersebut dipandang sebagai sebuah keharusan yang harus dipatuhi. Kondisi ini membuat guru tidak memiliki keleluasan untuk menerapkan prinsip-prinsip pembelajaran yang dapat digunakan untuk memfasilitasi siswa agar mampu melakukan konstruksi pengetahuan yang dipelajari. Waktu yang dimiliki oleh guru habis terpakai hanya untuk memenuhi tercapainya target kurikulum yang ditetapkan.

Kondisi di atas mengakibatkan pembelajaran berlangsung kaku, kering dan membosankan. Proses pembelajaran yang berlangsung setiap hari tidak mampu memotivasi dan menggairahkan siswa untuk menggali pengetahuan, keterampilan dan sikap yang perlu dimiliki. Hal ini bertentangan dengan pandangan tentang aktivitas belajar kondusif yang hanya dapat dicapai nelalui kegiatan belajar yang menyenangkan.

Masalah-masalah di atas perlu diceremati agara dapat dihasilkan solusi yang tepat. Guru perlu diberi keleluasaan untuk berkreasi dalam mendesain dan mengembangkan program pembelajaran yang efektif dan efisien. Oleh karena itu, guru diharapkan mampu menciptakan pembelajaran yang berkualitas. Salah satu kegiatan merancang pembelajaran yang berkualitas adalah mendesain strategi pembelajaran yang tepat.

Selama ini guru hanya menjalankan praktek pembelajaran berdasarkan buku, bahan ajar yang telah disusun oleh pemerintah. Guru belum pernah dan bahkan tidak pernah menjadi dsain sekaligus sebagai arsitektur perencanaan pembelajaran baik yang berkaitan dengan analisis instruksional, desain istruksional dan mengembangkan pembelajaran. Salah satu aspek penting dalam tahap desain instruksional adalah merancang strategi instruksional. 


\section{Jurnal Riset Pendidikan Dasar, 01 ( 2), Oktober 2018 (140-151)}

Yohanes Vianey Sayangan

Mengapa strategi instruksional itu penting? Guru tidak akan mudah menetukan materi atau topik pembelajaran yang akan dibahas bersama siswa apabila tidak mengetahui tujuan pembelajaran yang akan dicapai. Termasuk dalam meanentukan waktu yang diperlukan untuk melakukan kegiatan pembelajaran. Juga penting untuk menentukan metode dan media pembelajaran yang sesuai dengan kegiatan pembelajaran. Semua unsur tersebut di atas hanya bisa dijalankan apabila seorang guru telah mahir menjadi seorang desain dan arsitek dalam manghasilkan strategi pembelajaran yang tepat guna.

Dick, Carey dan Carey (2009: 166) mengatakan bahwa "Instructional strategy is used generallyto cover the various aspects of choosing a delivery system, sequencing and grouping clusters of content, describing learning components that will be included in the instruction, specifying how students will be grouped during instruction, establishing lessons structures, and selecting media for delivering instruction".

Strategi pembelajaransecara umum digunakan untuk menemukan berbagai aspek untuk memilih sistem penyampaian, penginstrukturtan dan pengelompokan kelompok konten atau isi pembelajaran, menggambarkan komponen pembelajaran, menentukan bagaimana peserta didik akan dikelompokkan selama proses pembelajaran berlangsung, membangun struktur pemebelajaran, dan memilih media yang yang tepat untuk kegiatan pembelajaran.

Ahli lain, Gagne, Robert M., Wager, Walter W., Golas, Katharine C., Keller, Jhon M.(2005: 226) menjelaskan strategi instruksional sebagai berikut. "Instructional strategies are tools or techniques available to educators and instructional designers for designing and facilitating learning". Strategi pembelajaran adalah alat atau teknik yang tersedia untuk pendidik dalam merancang dan memfasilitasi belajar.

Strategi instruksional berkenaan dengan pendekatan dalam mengelola isi dan proses instruksional secara komprehensifuntuk mencapai satu atau sekelompok tujuan instruksional.Di dalamnya terintegrasi berbagai komponen yang meliputi urutan kegiatan pembelajaran, garis besar isi, metode, media \& alat, dan waktu belajar (dalam menit). (Suparman, 2012:241).

Pakar lain, Rothwell dan Kazanas (2004:221) mendefinisikan strataegi pembelajaran sebagai berikut: An instructional strategy is perhaps best understood as an overall plan governing instructional content (What will be taught?) and process (How will it be taught?).

Dengan demikian, dapat dikatkan bahwa strategi pembelajaran merupakan organisasi dan urutan kegiatan belajar. Kegiatan belajar merupakan upaya untuk mengatur seperangkat peristiwa eksternal untuk menginterpretasi, mengkonstruksi, dan manifestasi dari pengetahuan dan keterampilan bagi peserta didik. Peristiwa strategi pembelajaran akan bervariasi tergantung pada konteks, sumber daya, dan kebutuhan peserta didik.

Menurut Dick, Carey dan Carey (2009: 178-179), komponen-komponen belajar dalam strategi pembelajaran terdiri dari lima tahap kegiatan, yaitu, (1) Tahap awal (preinstructional activities), (2) Penyajian isi (content presentation), (3) Partisipasi peserta pelatihan (learner participation), (4) Penilaian (assessment), dan, (5) Kegiatan tindak lanjut (follow-through activites).

Kelima tahap tersebut merupakan salah satu bagian dari strategi pembelajaran.Setiap tahap terdiri dari langkah-langkah kegiatan.Tahap awal terdiri-dari kegiatan menarik perhatian, menjelaskan tujuan pembelajaran, menjelaskan, dan mengingatkan keterampilan prasyarat.Tahap presentasi isi terdiri dari menjelaskan isi dan memberikan bimbingan belajar.Tahap partisipasi peserta didik terdiri dari latihan dan umpan balik.Tahap penilaian terdiri dari tes keterampilan awal, tes awal, dan tes akhir.Tahap terakhir adalah kegiatan tindak lanjut yang terdiri-dari memberikan bantuan untuk mengingat kembali materi yang sudah dipelajari dan mempertimbangan Copyright O2018, JRPD, ISSN 2615 - 1723 (Print), ISSN 2615 - 1766 (Online) 
kemungkinan penerapan isi dan kompetensi yang telah dicapai dalam kehidupan atau bidang yang relevan.

Evaluasi yang dilaksanakan setelah para peserta didik menyelesaikan suatu kegiatan belajar tertentu merupakan dasar untuk memperoleh balikan (feedback).Tujuan utama evaluasi adalah memperoleh informasi dan kajian tentang pencapaian tujuan dan penguasaan bahan oleh peserta pelatihan. Hasil evaluasi digunakan untuk menentukan apakah ada di antara para peserta didik memerlukan bimbingan untuk mencapai tujuan, sehingga seluruh peserta didik dapat mencapai tujuan dan menguasai bahan belajar secara maksimal.

Salah satu aktor penting dalam meningkatkan kualitas pembelajaran adalah guru. Guru adalah jantungnya pendidikan. Sebagus apapun kebijakan pembelajaran dan sebaik apapun kurikulum, jika tanpa didukung tenaga guru yang profesional dan berkualitas, maka kualitas pembelajaran tidak akan efektif. Artinya peran guru yang bermutu dan profesional dalam kegiatan pembelajaran akan menunjukkan kualitas pembelajaran. Hal ini ditegaskan oleh UNESCO dalam laporan the International Commision on Education for Twentyfirst Century menytakan antara lain bahwa memperbaiki mutu pendidikan tergantung pada pengatahuan dan keterampilan, karakter personal,prospek profesional, dan motivasi yang tepat jika ingin memenuhi harapan stakeholder pendidikan.

Dalam proses pembelajaran, perlu mengisi ruang-ruang kegiatan yang tetlah direncanakan dan dipikirkan sebelumnya. Dalam pembelajaran, ruang-ruang yang perlu diisi dan dipikirkan oleh guru yaitu bagaimana guru menyusun strategi pada tahap-tahap pendahuluan, pengembangan, kesimpulan dan penutup yang diperlukan baik dalam aktivitas pembelajaran individual mapun kelompok (Reece \& Walker, 2001: 13).Dengan kata laiin, yang perlu disiapkan oleh guru dalam pembelajaran meliputi introduction, body, concluding, and assesment (Smith dan Ragan, 2007).

Itu berarti guru yang profesional harus mampu menciptakan blue print dalam merancang sebuah bangun pembelajaran yang mampu menampung kebutuhan peserta didik.Untuk itu guru harus mampu menyusun rencna dan strategi pembelajaran sebagai bagian bangunan pembelajaran yang kokoh bagi tereselanggaraanya kualitas pembelajaran yang beerkualitas.

Kesseluruhan uraian konsep, data, informasi dan permasalahan pada latar belakang tersebut itulah yang menjadi dasar peikiran penulis untuk melakukan peneliitian mengenai peran guru sebagai desainer strategi instruksional dalam upaya menikgaatkan kualitas pembeleajaran bagi guru SD.

Focus penelitian ini adalah masalah guru SD sebagai desainer instruksional dalam meningkatkan kualitas pembelajaran di sekolah.

Adapun maslah dalam penelitian ini adalah (1) Mengapa para guru belum mampu merancang strategi instruksioanl secara benar dalam upaya meningkatkan kualitas pembelajaran bagi peserta didik?(2) Bagaimana cara untuk meningkatkan kualitas pembelajaran melalui peran para guru sebagai desainer strategi instruksional yang handal?

Adapun tujuan dari penelitian ini adalah untuk (1) Menganalisis faktor penyebab belum berperanannya guru sebagai desainer instruksional secara benar dalam meningkatkan kualitas pelayanan pembelajaran bagi peserta didik dinsekolah.(2) Menemukan cara yang tepat dan efektif untuk meningkatkan kualitas pembelajaran melalui peran para guru sebagai desainer strategi instruksional yang handal.

\section{METODE}

Pendekatan yang digunakan dalam penelitian ini adalah Pendekatan Kualitatif dengan metode analisis deskriptif sebagaimana dijelaskan Locke, Spriduso dan Silferman

Copyright $@ 2018$, JRPD, ISSN 2615 - 1723 (Print), ISSN 2615 - 1766 (Online) 


\section{Jurnal Riset Pendidikan Dasar, 01 ( 2), Oktober 2018 (140-151)}

Yohanes Vianey Sayangan

dalam Creswell (2012: 147) bahwa: "Qualitative research is interpretative research. As such, the biases, values and judgment of the researches become stated explicitly in the research report. Such openness is considered to be useful and positive." Aktivitas penelitian dicirikan oleh kegiatan mengumpulkan, menggambarkan dan menafsirkan data tentang situasi yang dialami, hubungan kegiatan, sikap yang ditunjukkan dalam proses yang sedang berlangsung, serta kerjasama yang dijalankan.

Digunakannya metode penelitian kualitatif dimaksudkan untukmenemukan (uncover) dan memahami (understand) apa yang ada di balik fenomena yang akan diteliti. Metode kualitatif dapat memberikan rincian fenomena (the details of phenomenon) yang sulit diungkapkan dalam metode kuantitatif (Strauss dan Corbin, 1990:19).

Pendekatan kualitatif dipilih untuk menjawab masalah penelitian yang diajukan, lebih ditekankan untuk mengungkapkan meaning dan memahami poses belum berperanannya guru sebagai desaier dan arsitektur di bidang strategi instruksional di sekolah-sekolah wilayah Riung Barat.

Dengan demikian, tujuan pemilihan pendekatan kualitatif ini adalah untuk memahami bagaimana proses dan mengungkapkan makna dari setiap fenomena sebagaimana adanya mngenai peran guru sebagai kreator untuk desain dan penembangan sistem instruksional dalam upaya meningkatkan kualitas pembelajaran bagi peserta didik.

Rincian data yang dibutuhkan meliputi data primer dan data sekunder. Data primer yakni data yang langsung direkam di lapangan melalui wawancara mendalam dan observasi oleh peneliti sendiri sebagai instrumen penelitian.

Data sekunder adalah data yang sudah diolah dan dipublikasikan secara resmi yang diperoleh dari hasil rencana strategis (renstra), program pembangunan daerah (Propeda) di bidang pendidikan serta dokumentasi dan media pemberitaan resmi.
Teknik analisis data menggunakan triangulasi data yakni teknik menguji kesahihan atau validitas, keterandalan atau reliabilitas data dan informasi yang terkumpul melalui teknik triangulasi dengan melibatkan semua narasumber serta melakukan cek silang validitas data.

\section{HASIL DAN PEMBAHASAN}

\section{Hasil Penelitian}

Berdasarkan hasil penelitian lapangan sebagai upaya untuk memperoleh jawaban atas masalah mengapa guru belum mampu menjadi desain strategi instruksional serta upaya untuk meningkatkan peran guru sebagai desainer strategi instsruksional dalam meningkatkan kualitas pembelajaran ditemukan beberapa aspek penting, yaitu: Pertama, faktor-faktor yang mempengaruhi rendahnya kemampun guru dalam mendesain strategi instruksional ditentukan oleh (1)) factor lingkungan dan budaya. (2) factor sumber pengetahuan yang terbatasdalam meningkatakan kinerja. (3) masalah motivasi (4) factor akses informasi dan telekomunikasi.

Kedua, upya yang dilakukan untuk Upaya meningkatan Kemampuan Kualitas Guru Sebagaii Desainer Stareti Instruksional. (1) Meningkatkan Kapasistas Para Guru Melalui Pendidikan dan Pelataihan.(2) Menjadi Desainer Strategi Instruksional yang Sesungguhnya. (3)menerapkan praktek mendesainStrategi Instruksional bagi semua guru dalam menyusun perangkat pembelajaran di sekolah.

Berikut ini akan dijelaskan factor-faktor yang mempengaruhi rendahnya kemampuan guru menjadi seorang desain strategi instruksional. (1)faktor lingkungan dan budaya. Faktor lingkungan dan budaya sangat berpengaaruhnya terhadap keberadaan para guru di gugus 2 Kecamatan Riung Barat.Lingkungan sosial dan budaya diartikan sebagai kebiasaan, tradisi, ikatan-ikatan yang menjadi habitus masyarakat setempat sebagai satu paguyuban.Lingkungan social dan budaya

Copyright (C2018, JRPD, ISSN 2615 - 1723 (Print), ISSN 2615 - 1766 (Online) 
masyarakat setempat tidak mengalami banyak perubahan dan perkembangan menuju kemajuan yang ditandai adanya kemajuan di bidang pendidikan.Tidak banyak perubahan pada pola pikir masyarak setempat yang dipengaruhi kekuatan pendidikan.Pendidikan masyarakat setempat masih memprihatinkan.Masyarakat setempat belum sepenuhnya menaruh perhatian pada kemajuan pendidikan.

Dari data tentang kondisi sosio edukasi, diketahuai bahwa $15 \%$ waraa masyarakat berpndidikan Sekolah Menengah Tingkat Pertama, dan Dasar, SMA 10 \%, S1 2 $\%$. Selebihnya tidak menamatkan pendidikan sekolah dasar.

Para guru menjadi tidak berkembang karena factor kultur dan kondisi laingkungan social edukasi dalam komunitas setempat. Lingkungan social yang jauh dari perkembangan dan perubahan yang dipicu kemajuan IPTEK menjadikan alasan logis bahwa komunitas masyarakat tersebut bukanlah komunitas belajar.Hal demikian berpengaruh pada kondisi dan eksistensi para guru.Para guru akhirnya terpaku pada tradisi masyarakat yang statis.Sebagai konsekwensinya para guru hanya mengandalkan pengetahuannya yang diperoleh pada saat belajar di bangku sekolah atau kuliah.

Fakta di atas ternyata dialami hamper oleh semua guru SD yang berada di Gugus 3 Kecamatan Riung Barat.

Total jumlah guru dari 3 SD segugus 2 Kecamatan Riung Barat berjumlah 25 orang. Dari 25 orang 17 yang berpredikat S1.Ratarata guru-guru SD meerupakan orang asli.Hanya 3 orang yang berasal dari luar daerah.

Dari hasil wawancara dan observasi menunjukan masalah yang sama di SD dari Gugus 2 Kecamatan Riung Barat, bahwa “...situasi masyarakat di Riung Barat berada dalam persoalan ketertinggalan di bidang pendidikan. Banyak anak yang tidak tuntas belajar di bangku sekolah dasar.Masalah itu terjadi karena tidak ada semacam kesadaran bersama untuk memajukan dunia pendidikan. Guru juga kurang berperan dalam membangun pendidikan yang berarti karena guru sendidiri terbatas kemampuan. Apalagi guru berada di wilayah yang jarang dijangkau kemajuan."

Dengan demikian, dapat dikatakan bahwa factor lingkungan social dan budaya akan berpengaruh pada kemajuan dan perkembangan pendidikan. Masyarakat yang kurang menghargai kemajuan pendidikan memberi kontribusi yang berarti pada kemiskinan dan kebodohan.Guru juga menjadi bagian dari situasi tersebut, dan guru akhirnya terbawa arus situasi yang tidak menentu dalam perubahan dan pembangunan pendidikan yang berkualitas.

(2) Factor sumber pengetahuan yang terbatas.Pengetahuan dan ilmu pendidikan selalu berubah dan selalu berinovasi sesuai perkembangan zaman dan perkembangan teori baru yang disesuaikan dengan kondisi dan kebutuhan peserta didik di era digital ini.Sebagai konsekwensinya, para guru juga harus selalu mengikuti kemajuan ilmu pengetahuan.Dalam kenyataannya, Para guru yang berada dalam Gugus 2 Kecamatan Riung Barat kurang memiliki keinginan untuk membuka wawasan serta memperkaya diri untuk belajar pada hal yang baru melalui kemajuan iptek.

Para guru tidak mampu mengembangkan teori dan praktek pembelajaran yang terkini dalam hal memperkaya ilmu bidang desain instruksional secara khusus bagaimana menjadi desainer bidang strategi instruksional.

Dari hasil analysis berdasarkan pengamatan serta studi mendalam ditemukan fakta bahwa sangat sulit bagi para guru yang memenerima kondisi yang ada (taken for the granted) akan berubah. Para guru sendiri tidak mampu mengembangakan pengetahuan dan pengalaman yang dimiliki karena para guru sudah puas dengan yang ada.Bahkan para guru merasa tidak penting untuk mengembangkan pengetahuan.Alasannya karena keberadaan di 


\section{Jurnal Riset Pendidikan Dasar, 01 ( 2), Oktober 2018 (140-151)}

Yohanes Vianey Sayangan

lokasi yang tidak memiliki akses pengetahuan.Di samping itu, para guru yang berasal dari daerah sendiri lebih banyak waktu diluangkan untuk mengurus kebun dan ternak.

Dengan kata lain, para guru tidak memiliki kemauan untuk belajar dan mencari sumber pengertahuan baru melalui media yang ada seperti pengadaan buku baru, mecari teori dan pengetahuan baru. Para guru telah memposisikan diri lebih sebagai petani.

(3) Factor motiasi kinerja yang rendah. Motivasi bagi setiap personil dalam satu instansi menjadi salah satu unsur penting dalam mencapai tujuan bersama. Termasuk dalam duni pendidikan. Sebuah sekolah sebagai lembaga, sebagai sebuah organisasi perlu merumuskan tujuan bersama. Untuk mencapai tujuan bersama, ditentukan banyak faktor. Salah satunya adalah faktor motivais. Namun dalam kenyataannya, faktor motivasi yang dinilai sebagai sesuatu yang dirasakan sangat penting, justeru dialami sebagai sesuatu yang sulit bagi para guru. Hal ini disebabkan karena beberapa alasan, antara lain (1) motivasi sebaai sesuatu yang penting (important subject). Dikatakan penting karena peran pemimpin itu sendiri ada kaitannya dengan bawahannya. Tiap pemimpin tidak boleh tidak harus bekerja bersama-sama dan melalui orang lain atau bawahan, untuk itu diperlukan kemampuan memberikan motivasi kepada bawahan. Hal ini yang tidak dijumpai dalam sebuah lembaga pendidikan Sekolah Dasar di Gugugs 2 Kecamatan Riung Barat. Yang dijumpai antara kepala sekolah dan para guru sebagai kolega tidak berjalan berjalan sebagai rekan kerja yang baik. Kepala sekolah kurang menunjukkan diri sebagai leader. (2) motivasi sebagai suatu yang sulit ( puzzling subject). Dikatakan sulit sebab, motivasi sendiri tidak bisa diamati dan diukur secara pasti. Dan untuk mengamati dan mengukur motivasi berarti harus mengkaji lebih jauh perilaku masing-masing bawahan.

Sulitnya memotivasi bagi para guru yang menjalankan tugasnya sangata erat kaitannya dengan keberadaan seorang pemimpin. Dari hasil wawamara dari beberapa tokoh pendidikan disimpulkan bahwa masalah rendahnya motivasi dalam membangun kesadaaran sebagai guru disebabkan faktor ketidakmampuan pimpinan memberikan motivasi kepada bawahan dalam hal ini kepada para gurut yang langsung menangani masalah disektor ril yakni di sekolah-sekolah. Selain itu, kesulitan lainnya adalah cara atau metode motivasi bagi para guru yang ada sangat sulit dilakukan karena guru beerjalan sendirian di lapangan.

Dengan kata lain, rendahnya kinerja para guru sangat erat terkait dengan lemahnya motivasi yang diberikan atasan atau pemimpin. Hal ini sangat nampak dalam melemahnya kinerja aparat yang melayani pendidikan di sekolah-sekolah. Para guru tidak mampu mengembangakan sistem pendidikan yang baik. Para guru tidak mampu menunjukkan kinerja yang baik dalam meningkatkan kualitas pembelajaran yang baik.

Buruknya kinerja para guru yang disebabkan oleh rendahnya motovasi kerja diungkapkan juga oleh seorang akademisi. Motivasi kerja para guru sangat rendah. Para guru tidak terpacu untuk menjalankan tugas sebagai pelayan dan pengabdi bidang pendidikan. Para guru yang ada tidak merasa memiliki tugasnya (sense of duty). Mereka bekerja hanya memenuhi tuntutan rutinitas belaka. Hal ini disebabkan karena tidak adanya proses interaksi kerja sama antara pemimpin dengan bawahan, kolega maupun dengan atasan pemimpin itu sendiri. Yang kedua, motivasi tidak terjaga di dalam kalangan para guru karena adanya budaya apatis. Kesannya tidak mau saling memahami, tidak tercipta iklim saling pengertian di antara para guru untuk meningkaatkan kompetnsi dan kualifikasi.

Jadi, ada masalah yanag menyebabkan guru kurang menyiapkan diri dalam Copyright O2018, JRPD, ISSN 2615 - 1723 (Print), ISSN 2615 - 1766 (Online) 


\section{Jurnal Riset Pendidikan Dasar, 01 ( 2), Oktober 2018 (140-151)}

Yohanes Vianey Sayangan

mengembangkan bahan pembelajaran seara baik dan sistematis, muali dari tidak memiliki kemampuan untuk melakukan persiapan pembelajaran yang dimulai dengan bagaimana melakukan desain instruksional tetmasuk melakukan desain strategi isntruskional sebagai bagian terpenting dalam pembelajaran.Hal ini disebebkan guru tidak memiliki motivasi untuk berkineja secara professional.Motivasi baik dari kesadaran sendiri maupun yang berasal dari dorongan luar seperti dukungan pimpinan.

(4) Factor keempat, sumber informasi dan teknologi yang terbarui yang tidak dapat diperoleh melalui pemanfaatan teknologi informasi.Para guru umumnya memiliki keterbatasan dalam menguasai dan menggunakan system informasi melalui dunia internet.Akses internet masih merupakan hal yang belum tersentuh dan terakses.Sebagai konsekwensinya para guru tidak dapat menangkap dan mendapatkan sumber pengetahuan dari dunia internet.Tidak mengherankan pengetahuan mengeanai dunia pembealajaran serta teori kontemporer tetang pembelajaran sangat minim.

Berangkat dari masalah yang dihadapi para guru untuk menjadi desainer strategi instruksional yang handal, maka perlu dicari upaya peningkatan kretivitas bagai guru agar bisa mencapai predikat sebagai desainer strategi instruksional.Adapun upaya yang dilakukan untuk meningkatan Kemampuan Kualitas Guru Sebagaii DesainerStareti Instruksional sebagai berikut. (1) Meningkatkan Kapasistas Para Guru Melalui Pendidikan dan Pelataihan. Istilah pelatihan merupakan terjemahan dari kata " training "(bahasa Inggris). Secara harfiah akar kata "training" adalah "train", yang artinya pelatihan. Pelatihan diartikan sebagai proses belajar yang melibatkan penguasaan pengetahuan, penajaman keahlian, konsep, yang pada gilirannya dapat mengubah sikap dan perilaku untuk meningkatkan kinerja peserta. Dengan kata lain, pelatihan berkaitan dengan penguasan pengetahuan, skill melalui upaya pengembangan professional.
Pernyataan di atas dapat ditafsirkan bahwa pelatihan adalah tindakan meningkatkan pengetahuan dan ketrampilan seorang untuk melaksanakan pekerjaan atau kegitan tertentu melalui proses untuk mengembangkan bakat, ketrampilan, dan kemampuan peserta pelatihan guna menyelesaikan pekerjaan atau kegiatan tertentu.

Pelatihan biasa dihubungkan dengan pendidikan.Hal ini terutama karena secara konsepsional pelatihan tidak dapat dipisahkan dari pendidikan, meskipun demikian secara khusus pelatihan dibedakan dari pendidikan.Pelatihan biasanya diasosiasikan pada mempersiapkan seseorang dalam melaksanakan suatu peran atau tugas, biasanya dalam dunia kerja. Namun demikian, pelatihan bisa juga dilihat sebagai elemen khusus atau keluaran dari suatu proses pendidikan yang lebih umum.

Dengan demikian, dapat dikatakan bahwa pelatihan pada dasarnya meliputi proses belajar mengajar dan latihan yang bertujuan untuk mencapai tingkatan kompetensi tertentu atau efisiensi kerja. Sebagai hasil pelatihan, peserta diharapkan mampu merespon dengan tepat dan sesuai situasi tertentu.Seringkali pelatihan dimaksudkan untuk memperbaiki kinerja yang langsung berhubungan dengan situasinya.

Melalui pendidikan dan pelatihan para guru dapat ditingkatkan kemampuan pedagogic dan kemampuan kinerja untuk menjadi seorang desainer intruksional. Pendidikan dan pelatihan yang dilakukan adalah proses memberikan pengetahuan baru, pengalaman kontekstual bagi para guru tentanga bagaimana merancang, merencanakan dan mendesain strategi instruksional secara baik dan benar.

Kegiatan pelatihan dan pendidikan bagi para guru harus dilaksanakan secara sistematis, terencana dan terjadwal.Perlu diorganisir secara professional.Yang terpenting dalam konteks ini adalah bagaimana menghadirkan pakar, instruktur yang 
professional dalam bidang desain dann pengembangan instruksional. Selain itu, ditentukan pula waktu dan tempat bagi terselenggaranya kegiatan pendidikan dan pelatihan desain strategi instruksional bagi para guru. (2) Menjadi Desainer Strategi Instruksional yang Sesungguhnya.Desain pembelajaran (instructional design) bukanlah istilah baru dalam dunia pembelajaran. Desain pembelajaran muncul sejak saat praktek pembelajaran itu ada. Kata "desain" sendiri dalam prosesnya identik dengan istilah arsitek. Istilah desain dan arsitek diartikan sebagai seni dalam merancang dan mendirikan bangunan, termasuk di dalamnya perenccanaan, konstruksi dan penyelesaian dekorasi. Arsitektur meliputi sifat atau bentuk bangunan, proses membangun bangunan, bangunan itu sendiri dan kumpulan bangunan. Aktivitas arsitektur menciptakan ruang dengan cara yang benar-benar direncanakan dan dipikirkan sebelumnya.

Sama halnya dengan arsitektur atau desasin bangunan membutuhkan seorang arsitek bangunanuntuk merancang dan merencanakan model, bentuk, ukuran dan artistik sebuah bangunan, pembelajaran juga sebuah bangunan yang butuh perenccanaan. Pemebalajaran didesain atau diarsitek oleh desainer atau arsitektur yang bernama guru, dosen, atau instruktur. Dalam pembelajaran, ruang yang perlu diisi dan dipikirkan oleh guru, instrutkur sebagai desainer atau aristek adalah bagaimana menyusun strategi pada tahap pendahuluan, pengembangan, kesimpulan dan penutup yang diperlukan baik dalam aktivitas pembelajaran secara individu maupun kelompok.Secara umum organisasi suatu pembelajaran meliputi introduction, body, conculuding and assesment.

Untuk menjadi seorang arsitektur di bidang strategi instruksional para guru harus memahami dan mengetahui apa yang menjadi tujuan dan urgensi penyusunan strategi instruksional. Yang harus diperhatikan para guru dalam menyusun strategi instruksional secara konkret adalah urut-urutan kegiatan seperti D, R, T, U, C, L, T, U dan komponen metode dan media serta waktu. D, R, T, U, C, $\mathrm{L}, \mathrm{T}, \mathrm{U}$ merupakan inisial. D: deskripsi singkat isi, R: relevansi dan manfaat, $\mathrm{T}$ : Tujuan instruksional khusus, U: Uraian, C: contoh dan non contoh, L: latihan, R: rangkuman, U: umpan balik, T: tindak lanjut.

Dalam desain atau arsitek bangunan perlu satu model bangunan. Ada banyak model bangunan. Demikiann juga dalam pembelajaran harus didasarkan pada model pembelajaran tertentu. Dan model pembelajaran ada banyak ragamnya. Pemilihan model pembelajaran tergantung kebutuhan. Dalam menyusun strategi instruksional para guru juga perlu memahami dan mengetahui model pembelajaran yang akan digunakan.

Dengan demikian,para guru harus mahir dalam bidang desain Instruksional yang juga desainer strategi instruksional sebagai suatukegiatan yang dilakukan secara sistematis untuk mengembangkan kegiatan pembelajaran untuk mencapai hasil yang optimal.

Selainitu denganimplementasi pendekatan system dalam merancang desain pembelajaranseorang pendesain instruksional dapat melihat secara holistik semuatahapan desain, berdasarkan pandangan tersebut dapat dilakukanevaluasi untuk memperoleh umpan balik dalam melakukan revisi dankoreksi dalam setiap langkah desain.

Demikian juga dengan desain strategi instruksional, seorang guru sebagai seorang desainer perlu memahami apa itu strategi instruksional. Strategi instruksional berkenaan dengan pendekatan dalam mengelola isi dan proses instruksional secara komprehensifuntuk mencapai satu atau sekelompok tujuan instruksional.

Urutan kegiatan pembelajaran menunjukkan langkah-langkah pembelajaran yang sesuai dengan sintaks dari metode atau kombinasi dari beberapa metode.Pada prinsipnya format kegiatan pendahuluan dan penutup bersifat konstan atau tetap, sedangkan langkah-langkah penyajian bersifat dinamis

Copyright (2018, JRPD, ISSN 2615 - 1723 (Print), ISSN 2615 - 1766 (Online) 


\section{Jurnal Riset Pendidikan Dasar, 01 ( 2), Oktober 2018 (140-151)}

Yohanes Vianey Sayangan

sesuai dengan sintaks dari metode yang digunakan.

Secara garis besar ada tiga tahap: pendahuluan, penyajian, dan penutup. Rincian setiap tahap ditentukan berdasarkan teori belajar dan prinsip pembelajaran tertentu sesuai pilihan designer ;Khusus tahap penyajian, urutan kegiatan pembelajaran harus terkait dengan sintaks (syntax) atau langkahlangkah setiap pendekatan/metode pembelajaran yang dipilih.

Tahapan-tahapan inilah yang harus dipahami oleh seorang guru sebelum mendesain sebuah system bangunan strategi instruksional.Seorang guru haaus memiliki sebuah konsep serta model untuk membangun strategi instruuksional. Setelah memiliki pengetahuan, pemahaman serta model strategi instruksional, seorang guru pada tahap selanjutnya mulai mempraktekan dengan menerapkan cara membuat strategi instruksional sesuai langkah dan tahaptahapannya. (3)Menerapkan Praktek MendesainStrategi Instruksional dalam Menyusun Perangkat Pembelajaran di Sekolah.Pada tahap ini para guru diarahkan untuk membuat atau menyusun tahapan strategi instruksional.Penyusunan strategi isntruksional oleh para guru haruslah didasarkan atas tujuan instruksional yang akandiccapai sebagai kriteria utama. Hal-hal yang perludiperhatikan adalah, bagaimana tahap awal pembelajaran akandilaksanakan, bagaimana penyajian materi, bagaimana partisipasipeserta didik, bagaimana melakukan penilaian, dan kegiatan tindaklanjut apa yang perlu diambil.

Strategi instruksional didasari oleh tujuan pembelajaran atau TIK yang telah dirumuskan sebelumnya. Dalam menyusun strategi instruksional juga perlu diperhatikan tahapantahapan, yaitu tahap pendahuluan, tahap penyajian yang merupakan kegiatan inti, dan tahap penutup. Mengembangakan bahan pembelajaran. Bahan pelajaran yang dikembangkan meliputi tiga bentuk, yaitu 1) sistem pembelajaran mandiri, 2) sistem pembelajaran tatap muka, 3) sistem pembelajaran kombinasi. Pengembangan bahan pembelajaran harus didasarkan pada strategi instruksional yang telah disusun.

Jadi proses mendesain instruksional tidak pernah dimulai dengan menentukan bahan instruksional (instructional matrials)

Penjabaran tujuan instruksional umum menjadi tujuan instruksional khusus dilakukan melalui proses analisis instruksional, tidak melalui penetuan pokok bahasan (isi). Pembuatan tes didasarkan pada tujuan instruksional bukan pada bahan instruksional (instructional materials)

Penentuan isi (content) didasarkan pada tujuan instruksional, bukan sebaliknya. Penentuan metode dan media \& alat didasarkan pada kesesuaiannya dengan tujuan pembelajaran dan karakteristik peserta didik.

Penentuan alokasi waktu pembelajaran didasarkan pada kemungkinan ketercapain tujuan pembelajaran bila menggunakan langkah-langkah kegiatan pembelajaran, lingkup isi, metode, media \& alat.

\section{PEMBAHASAN}

Semua tahapan dalam desain instruskional merupakan langkah dalam menjabarkan isi pembelajaran yang dijalankan seorang guru. Apapun perubahan kuirikulum baik secara nasional maupun sampai pada taraf implementasi dan aplikasi, desain instruksional tetap merupakan vehicle yang mewujdukan tujuan pendidikan dan kualitas pembelajaran di sekolah.Guru tetap menjadi sosok sentral yang disebut desainer instruksional. Desain insruksional mewujudkan pelaksanaan tujuan pendidikan yang dijabarkan melalui sebuah sistem pengembangan pembelajaran di sekolah. Pelaksnaannya adalah seorang desainer instruksional yang mewujud dalam diri seorang guru.

Dalam desain instruksional hal yang perlu diperhatikan oleh guru adalah menjawab tujuan dari pendidikann di sekolah yakni rencana dan pengaturan tentang isi dan bahan pembelajaran serta cara yang digunakan 


\section{Jurnal Riset Pendidikan Dasar, 01 ( 2), Oktober 2018 (140-151) \\ Yohanes Vianey Sayangan}

sebagai pedoman penyelenggaraan kegiatan pendidikan dan pembelajaran.Dengan deikian, desain instruksional merupakan sebuah sistem yang menjamin tujuan dari pendidikan, baik dari aspek makna maupun tujuan serta implementasinya.

Ada tiga tahap proses desain instruksional yang harus dilalui dalam proses pembelajaran yang dilakukan seorang guru. (1) tahap I : mendefinisikan masalah (mengidentifikasi kebutuhan instruksional, merumuskan tujuan instruksional umum, melakukan analisis instruksional, mengidentifikasi prilaku \& karakteristik awal peserta didik dan mendeskripsikan latar/setting), (2) tahap II: analisis dan pengembangan sistem instruksional

(menulis tujuan instruksional khusus, menulis tes acuan patokan, menyusun strategi instruksional, dan mengembangkan prototipa sistem instruksional), (3) tahap III: Evaluasi formatif terhadap prototipa sistem instruksional (review pakar \& revisi, uji coba skala kecil \& revisi, dan uji coba skala luas yang melibatkan masyarakat pengguna lulusan \& revisi)

Dari tahapan-tahapan desain instruksional tersebut di atas, hal yang penting dan mendapat perhatian dalam menunjang proses pembelajaran, adalah mendesain strategi instruksional. Mengapa strategi pembelajaran penting?

Strategi pembelajaransecara umum digunakan untuk menemukan berbagai aspek untuk memilih sistem penyampaian, uruturutan dan pengelompokan konten atau isi pembelajaran, menggambarkan komponen pembelajaran, menentukan bagaimana peserta didik akan dikelompokkan selama proses pembelajaran berlangsung, membangun struktur bidang pelatihan, dan memilih media pembelajaran.

Dalam stategi instuksional akan dijabarkan deskripsi singkat tentang apa yang menjadi relevansi dan manfaat pemeblajaran, dan apa kompetensi atau tujuan khusus (TIK) dalam mencapai tujuan pembelajaran. Dalam strategi instruksional juga akan dijabarkan tahap penyajian.

Tabel 1.Tabel menyusun Strategi instruksional

\begin{tabular}{|c|c|c|c|c|}
\hline $\begin{array}{l}\text { URUT } \\
\text { AN } \\
\text { KEGI } \\
\text { ATAN } \\
\text { PELA } \\
\text { TIHA } \\
\mathrm{N}\end{array}$ & $\begin{array}{c}\text { GARIS } \\
\text { BESAR } \\
\text { ISI/MA } \\
\text { TERI }\end{array}$ & METODE & $\begin{array}{c}\text { MEDIA } \\
\& \\
\text { ALAT }\end{array}$ & $\begin{array}{l}\text { WAKTU } \\
\text { BELAJAR } \\
\text { (dalam } \\
\text { menit) }\end{array}$ \\
\hline 1 & 2 & 3 & 4 & 5 \\
\hline \multicolumn{5}{|c|}{ TAHAP PENDAHULUAN } \\
\hline $\begin{array}{l}\text { Deskri } \\
\text { psi } \\
\text { singkat } \\
\text { isi }\end{array}$ & & & & \\
\hline $\begin{array}{l}\text { Releva } \\
\text { nsi \& } \\
\text { Manfa } \\
\text { at }\end{array}$ & & & & \\
\hline TIK & & & & \\
\hline \multicolumn{5}{|c|}{ TAHAP PENYAJIAN } \\
\hline $\begin{array}{l}\text { Uraian } \\
\text { / } \\
\text { contoh } \\
\& \text { Non } \\
\text { Conto } \\
\text { h }\end{array}$ & & & & \\
\hline $\begin{array}{l}\text { Conto } \\
\mathrm{h} \quad \& \\
\text { Non } \\
\text { Conto } \\
\mathrm{h} \\
\text { /Uraia } \\
\mathrm{n}\end{array}$ & & & & \\
\hline \multicolumn{5}{|l|}{$\begin{array}{l}\text { Latiha } \\
\mathrm{n}\end{array}$} \\
\hline \multicolumn{5}{|l|}{$\begin{array}{l}\text { Tes } \\
\text { Forma } \\
\text { tif }\end{array}$} \\
\hline \multicolumn{5}{|l|}{$\begin{array}{l}\text { Rangk } \\
\text { uman }\end{array}$} \\
\hline \multicolumn{5}{|c|}{ TAHAP PENUTUP } \\
\hline $\begin{array}{l}\text { Umpa } \\
\text { n Balik }\end{array}$ & & & & \\
\hline $\begin{array}{l}\text { Tindak } \\
\text { Lanjut }\end{array}$ & & & & \\
\hline Jumlah & ktu & & & \\
\hline
\end{tabular}

Dalam tahap penyajian inilah muatan materi dari berbagai jenis mata pelajaran akan bisa dikolaborasi. Model pembelajaran mana saja dirancang dalam tahap penyajian untuk mendukung tujuan pembelajaran yang dimaksud. Hal penting yang perlu diperhatikan adalah pola pendekatan dalam penyajian materi, yaitu penedekatan induktif: contoh-non contoh, uraian dan latihan (CUL) untuk kelompok anak-anak (pedagogi) \& pendekatan deduktif: uraian, contoh-non contoh dan latihan (UCL) bagi orang dewasa (androgogi).

Copyright (C2018, JRPD, ISSN 2615 - 1723 (Print), ISSN 2615 - 1766 (Online) 
Dalam strategi instruksional juga dirancang apa media serta metode pembelajaran yang akan digunakan srta alokasi waktu.

Desain strategi instruksional juga perlu memperhatikan tahap penutup. Tahap ini terdiri dari tes formatif dan umpan balik serta tindak lanjut. Tes formatif dan umpan balik diperlukan untuk mengidentifikasi kesulitas yang dihadapi dalam tes. Sedangkan tindak lanjut berkaitan dengan menjelaskan kembali bagian-bagian yang belum dimengerti.

Berdasarkan strataegi pembelajaran inilah, akan memungkinkan disusunnya bahan ajar (learning materials). Secara umum strategi instruksional harus memuat tahapan-tahapan: tahapan pedahuluan, tahapan penyajian dan tahapan penutup. Dalam tahapan strategi isntruksional juga memuat usnur metode, media pembelajarn dan waktu.Berikut ini dipaparkan contoh krangka strategi instruksional pada table berikut ini.

\section{SIMPULAN}

Para guru belum mampu merancang strategi instruksioanl secara tepat dalam upaya meningkatkan kualitas pembelajaran bagi peserta didik. Hal ini disebabakan (1)factor lingkungan dan budaya masyarakat yang statis terhadap perubahan dan kemajuan IPTEK. (2) factor sumber pengetahuan yang terbatas sehingga para guru secara optimal belum mampu meningkatakan kinerja. (3) masalah motivasi (4) factor terhambatmnya akses informasi dan telekomunikasi.

Pengayaan kapasistas para Guru melalui pendidikan dan pelataihan, penerapan praktek mendesainStrategi Instruksional dalam menyusun perangkat pembelajaran di Sekolah, dan menjadi desainer trategi instruksional yang Sesungguhnya, dapatmeningkatkan kualitas pembelajaran melalui peran para guru sebagai desainer strategi instruksional yang handal.

\section{DAFTAR PUSTAKA}

Carey W. Dick, and Carey, L \& Carey, J. O. (2009).The Systematic Design of Instruction.New Jersey: Pearson.

Creswell, John, W., (2012). Research design, Qualitative and Quantitative Aproaches, Sage Publications, Thousand Oaks, London.

Evers, Tony, (2010). High Quality Instruction that Transforms. A Guide to Implementing Quality Academic Service Learning. Wisconsin: Wisconsin Departament of Public Insdtruction.

Gagne, Robert M., Wager, Walter W., Golas, Katharine C., Keller, Jhon M. (2005). Principles of Instructional Design. $\quad\left(5^{\text {th }}\right.$ ed). Belmont, CA: Wadsworth/Thomson Learning. (p. 226).

Gagne, R. M. and Briggs, L. J. (1979).Principles of Instructional Design (2' Ed.) New York: Holt, Rinehart and Winston.

Gagnon Jr., George W., and Collay, Michelle. (2001). Designig for Learning: Six Element in Constructivist Classrooms. Thousand Oaks, CA: Corwin Prees, Inc. A Sage Publication Company.

Reece, Ian dan Steephen Walker (2001). Teaching, Training, and Learning: A Practical Guide, Great Britain: Atheneum Press - Gateshead.

Reiser, Robert A., and Dempsey, Jhon V. (2012). Trend and Issues in Instructional Design an Technology (Third Edition). Boston: Pearson Education.

Rothwel, Wiliam J., and Kazanas, H.C. (2004).Mastering the Instruction Design Process: A Systematic Approach. USA.Pfeiffer.

Suparman, Atwi, 2012.Desain Instruktur Modern.Jakarta: Erlangga. 